\title{
The Diplomatic Teacher: The Purpose of the Teacher in Gert Biesta's Philosophy of Education in Dialogue with the Political Philosophy of Bruno Latour
}

\author{
Fredrik Portin ${ }^{1,2}$ (D) \\ Published online: 12 March 2020 \\ (c) The Author(s) 2020
}

\begin{abstract}
In this theoretical and explorative essay, two issues are discussed, which are based on personal experiences of teaching ethics. The first is what educational purpose does it serve to challenge students as ethical subjects while teaching a class? This issue is mainly discussed through an analysis of Gert Biesta's works. He argues that an essential purpose for teachers is to enable students to appear as subjects. For this to happen, the teacher must "interrupt" the students by presenting that which challenges his or her basic ethical preconceptions, which in turn forces the student to choose as a subject. However, if the teacher gives priority to such interruptions, s/he risks a conflict with his or her students. That gives rise to the second issue raised in the essay, whether the teacher should express his or her ethical perspectives while teaching ethics. The issue is discussed by analyzing Bruno Latour's political philosophy. He argues that conflict is an essential feature in any democratic society where everyone's concerns are presented. For that reason, he argues for the need of public "diplomats," whose function is to enable an endeavor for peace. As diplomats, both their ethical agency and ability to judge what is worth highlighting is recognized. Thus, the essay concludes that a diplomatic teacher is someone who has the judgement to decide whether his or her ethical perspectives should be highlighted while teaching a class, or if it would disrupt an endeavor for peace.
\end{abstract}

Keywords Ethics $\cdot$ Gert Biesta $\cdot$ Bruno Latour $\cdot$ Diplomacy $\cdot$ Conflict

As a scholar in political theory and philosophy of religion, one of my teaching responsibilities is ethics, mainly as it is expressed in world religions. As a teaching responsibility, it is

Fredrik Portin

fredrik.portin@lir.gu.se

1 Department of Literature, History of Ideas and Religion, University of Gothenburg, Gothenburg, Sweden

2 Department of Theological Ethics and Philosophy of Religion, Åbo Akademi University, Turku, Finland 
often gratifying, since topics within moral philosophy ${ }^{1}$ often engage students. ${ }^{2}$ In addition, because of the so-called renewed visibility of religion in public life (Calhoun et al. 2011), ${ }^{3}$ interest in religious practices and truth claims have become the subject of increased public interest, which further contributes to the engagement of the students.

My challenge in teaching ethics at universities is, therefore, not whether students are engaged. A recurring challenge is, on the other hand, to understand my role as a teacher of ethics and my agency as an ethical subject in my teaching. In this theoretical and explorative essay, I will address these issues with the help of the philosopher of education Gert Biesta's and the philosopher and sociologist Bruno Latour's works.

\section{Defining the Problem}

This essay will address two challenges I have faced as an ethics teacher. First, teaching ethics has great potential for conflict. ${ }^{4}$ Although there are exceptions, people do not generally take the time or even feel the need to discuss or reflect upon their values. On the contrary, our ethics most often constitute an unquestioned basic attitude, as we generally do question whether we live a good life or not (Kurtén 1995: 7-21). However, ethical reflection becomes necessary when confronted with an ethical conflict. For example, If we are confronted by different ethical perspectives than our own, we need to position ourselves ethically (unless we instead trivialize the conflict, of course).

Teaching how different actors relate to ethical questions can serve as such a confrontation of the student's basic and unquestioned ethical attitude. Therefore, teaching ethics is not just about teaching e.g. how different actors reflect on ethical questions, as well as different methodological, practical, and theoretical perspectives. It also has the potential to force the students to reevaluate his or her values. However, since such a confrontation is not always welcomed by students-it is not easy to have one's ethics questioned - an important question becomes: what right do I as a teacher in ethics have to challenge students as ethical subjects while teaching a class? And if I challenge the students, what educational purpose does such a confrontation serve?

Second, especially since I teach the ethics of world religions, the questions addressed are particularly sensitive. Therefore, when a student takes a clear ethical position while discussing a sensitive question, a conflict between students sometimes arise. It is important to note that significant conflicts are few, and when they do happen, it is usually quite easy

\footnotetext{
1 Some ethicists make a distinction between ethics and morality, where ethics is understood as the theoretical-narrative basis of moral practice. However, I will not make any distinction between these concepts.

2 Since the context discussed in this paper is university education, I will refer to the ones being educated as "students." However, the issues and perspectives that are highlighted also have relevancy outside of the university context.

3 Jürgen Habermas explains that this new visibility was mainly caused by the fact that global conflicts with religious undertones were brought to the public's attention, that religious actors are increasingly involved in public discussions, and that so-called "foreign" religious expressions-e.g. the veil—appeared as an increasingly visible part of everyday life in the West (Habermas 2008: 20-21. See also Moberg et al. 2012: 4).

4 Whenever "conflict" is discussed in this essay, it references a state of disagreement about something important between two or more actors or social groups. Specifically, the thing of importance pertain to values. "Conflict" should accordingly be understood as value-conflicts or ethical conflicts.
} 
to steer the discussion in a constructive direction. A major challenge, however, is how to handle situations where a student is in conflict with me.

The question of abortion can serve as an illustrative example. Questioning the right to abortion is controversial in the Nordic countries (where I have thought). However, I have an educational duty to present how (mostly Christian) abortion opponents reason. Given that few of the students count themselves as abortion opponents (or at least are willing to admit it), it becomes my responsibility to highlight abortion opponents' arguments, in order to get students to think beyond their ethical outlook. In the pursuit of neutrality, I have presented these arguments from certain methodological perspectives. However, despite this pursuit, it is not always possible to avoid a conflict. My experience is often that some students get upset with what is presented, and sometimes even noticeably upset with me, as they now associate me with a certain ethical or political opinion (which I do not even necessarily subscribe to). In order not cause permanent division between the students and me due to the conflict, I sometimes feel the need to position myself ethically while discussing a particular ethical question. This, in turn, entails that I depart from the principle of neutrality in teaching.

Thus, the students perceive that I am expressing my ethical agency when I am teaching, regardless of whether I strive for neutrality or not. Accordingly, a crucial question that arises is how, as a teacher, I should relate to my ethical agency when challenging the ethical positions of the students. Should I appear as an ethical actor in those situations? And if I do, does such an appearance conflict with my role as a teacher?

The two questions that I examine in this essay are thus: (1) What educational purpose does it serve to challenge students as ethical subjects while teaching a class? (2) How should teachers relate to their ethical agency when challenging the students as ethical subjects?

\section{Methodological Perspectives and Outline}

The question of ethics and teaching is an topic that has been debated in both ancient and modern philosophy, which has given rise to several debates about how teaching is best practiced and what effects the teaching of ethics should have for the general good of society. In these discussions, the question of the teacher's ethical agency has also been highlighted. Over the past 30 years, this question has been increasingly discussed by several scholars and philosophers of education, e.g. Carr (1993), Fenstermacher (2001), Hansen (2001), Sockett (1996), and Campbell (2003). Although these (and other) scholars address the question of ethics in teaching from different positions and with different questions, their thinking is characterized by the realization that the space for teaching is a morally multifaceted space, which poses major challenges for educators when engaging with students (Campbell 2008: 357).

This study is part of this ongoing discussion within educational studies. Furthermore, this study is theoretical and explorative. The purpose is thus not to present or interpret an empirical material. Instead, the purpose is to gather theoretical perspectives that can support a continued reflection on the topics discussed and enable future research. All references to my own experience should therefore not be perceived as holding any particular empirical value. Instead, it should be considered as illustrative for the theoretical perspectives discussed. Thus, the purpose of the essay is not to give any definitive or empirically based answers to the research questions explored. The hope is instead that, above all, 
teachers and teacher students will be able to, so to speak "think with" this essay, in order to be able to relate more thoughtfully to current or upcoming teaching assignments. Accordingly, although the defined problems are based on my experience, I argue that these issues have broader implications for all teachers and not just for those who teach ethics.

To address the defined problems, I will initially present Gert Biesta's understanding of the role of the teacher. As I will clarify, he believes that teaching should create opportunities for students to appear as subjects. Subjectification is accomplished by allowing the student to be confronted by that what is different, which in turn entails that they need to reflect on what is desirable. Biesta's works thus show why it is important for students to be confronted in order to be able to appear as a subject-something that often happens while teaching an ethics class - and how teachers can enable such a process of subjectification.

While Biesta can provide an initial description of the teacher's role, he only offers part of the answer to the problems outlined above. In order to address the question related to the ethical agency of the teacher, I will, therefore, bring Biesta into dialogue with Bruno Latour's political philosophy. Although Latour is a well-known name within the social sciences, his political philosophical approaches have not been given any major attention. ${ }^{5}$ For this reason, I will briefly present the essentials in Latour's political philosophy. Particular attention will be given to the conditions for political equality between different actors, as well as the role Latour attributes to the "diplomat" in enabling equality. ${ }^{6}$

\section{Making the Subject Appear While Teaching}

The starting point for Biesta's philosophy of education is a critique of what he describes as a "learnification of education." This describes a political and cultural process in which the language of education is increasingly construed as a "language of learning" that affect how one understands the purpose of education and educational practices (Biesta 2016: 18).

The language of learning describes a process where education is shaped primarily by market logic, and where education is understood as a form of economic transaction between autonomous actors. According to this understanding of education, the student is perceived as a consumer who seeks out a teacher and/or educational institution in order to satisfy a need for e.g. knowledge or some particular skills. According to Biesta, education thus becomes a product that is consumed by the customer - the student (Biesta 2006: 19-20). Thus, based on the language of learning, education will primarily be concerned with the process of learning, specifically how it can be more effectively achieved, so that the student gets, so to say, the most bang for their bucks. Moreover, education becomes individualized, which entails that the social aspects of education become secondary to the individual's—namely, the student's—personal preferences (Biesta 2006: 22-23).

\footnotetext{
5 An exception is Graham Harman, Bruno Latour: Reassembling the Political (Harman 2014).

6 The combination of Biesta's philosophy of education with political philosophical perspectives is motivated by the fact that Biesta himself studies political philosophy to develop his philosophical perspectives. The reason, he states, is that the challenges that teachers face are the same ones that exist within politics. Political theorists consequently give attention to the issues that Biesta want to raise, which, he argues, entails that the reflections conducted by political theorists tend to be more developed than within educational theory (Biesta 2006: 75-76). Furthermore, Biesta argues that the perspectives that he advances are not only essential for understanding education but also reflects an ideal for society. Biesta writes: "On a wider scale, questions about the content and purpose of education are [...] fundamentally political questions" (Biesta 2006: 23).
} 
If this is related to my teaching in ethics, an emphasis on learning would reduce the purpose of teaching to, e.g. only presenting how actors in the various world religions generally reason about questions related to ethics, as well as certain theoretical and methodological perspectives in ethical research. With Biesta, on the other hand, I can argue that I am not needed to realize such a purpose (see Biesta 2013: 59-68, 126-127). Instead, my role could crudely put be limited to the examination of the students, where I review what they have learned by reading the material contained in the course literature, while anything beyond that would fall outside my obligation as a teacher. If the students change their ethical perspectives and practices during one of my courses in ethics, it will accordingly be a side effect of the learning process, but not an educational purpose in itself.

According to Biesta's reasoning, teaching that only facilitates learning proceeds from a narrow view of the purpose of teaching. According to Biesta, teaching is about more than merely disseminating knowledge to the consumer-student. Biesta writes: "In its shortest formula the issue here is that the point of teaching, and of education more generally, is never that students 'just' learn, but always that they learn something, that they learn it for particular reasons, and that they learn it from someone" (Biesta 2017: 27-28). Biesta thus believes that education is related to questions about content, purpose and relationships, which he believes that the language of learning does not provide any answers to. And if teaching is increasingly understood according to a language of learning, the greater the risk that all these questions are not addressed: "The danger with the rise of the language of learning in education is that [questions about content, purpose, and relationships] are no longer asked, or that they are already taken to be answered" (Biesta 2017: 28). ${ }^{7}$ To counteract an understanding of education that avoids questions about content, purpose and relationships, Biesta, therefore, wants to highlight what he describes as a "language of education." And it is specifically the question of purpose that Biesta believes is the most important to consider (Biesta 2017: 28).

According to Biesta, discussions about the purpose of education should concern three different functions: qualification, socialization, and subjectification. The most obvious example for the process of qualification is learning a vocational skill. Qualification accordingly concerns how teaching contributes to the learning of specific abilities and knowledge, which in turn enables students to function effectively in society when performing different tasks and confronting different challenges. Socialization, in turn, concerns how teaching incorporates students into a specific social, cultural, or political order. This is done in particular by communicating different norms and values through education. Finally, subjectification is about how teaching contributes to the student becoming a subject. Unlike socialization, subjectification is not about the student becoming part of an established order. Instead, it is about the student breaking away from the norms and values that govern such orders. Subjectification is thus about how students, as Biesta writes, "can be independentor as some would say, autonomous_-subjects of action and responsibility" (Biesta 2013: 64).

\footnotetext{
7 Biesta generalizes and thinks that the language of learning can, for example, shape education so that "the only relevant content is academic content, that the only relevant purpose is academic achievement, and the only relevant relationship is for teachers to train students so that they generate the highest possible test scores, for themselves, their school, and their country" (2017: 28).
} 
While it is important for the teacher to strike a good balance between all these three purposes (Biesta 2017: 29), ${ }^{8}$ it is above all the question of subjectification that Biesta emphasizes and develops in his philosophy of education. He even argues that any education that is worthy of being described as such includes a process of subjectification. He writes: "[Any] education worthy of its name should always contribute to processes of subjectification that allow those educated to become more autonomous and independent in their thinking and acting" (Biesta 2016: 21).

It is by emphasizing that education can and should be about subjectification, that the process of personal ethical development while teaching ethics can be understood. If one accepts Biesta's normative claim that education should relate to subjectification-something that is not a given, but which can, in any case, be highlighted as a teaching purpose if you deviate from the language of learning - then the student's ethical development will be a relevant educational purpose. It accordingly becomes important that the student can "appear as a subject" (see Nancy 1991: 7; Biesta 2006: 42-43; Winter and Biesta 2013: 143) through education.

\section{The Purpose of the Teacher}

To develop the understanding of what it means to appear as a subject, Biesta turns to the works of Hannah Arendt and Emmanuel Levinas.

In Arendt's works, Biesta emphasizes how a subject's agency-what Arendt describes as action (see Arendt 1998; Biesta 2006: 47-48; Biesta 2013: 104-105) - is related to the question of plurality. To appear as a unique subject cannot be understood as forcing one's presence on others, thus requiring others to tolerate or adapt to how one acts. Accordingly, subjectivity is not about the freedom to realize oneself by making room for one's dreams and desires, sometimes at the expense of other people's agency. Acting as a subject instead entails allowing others the opportunity to appear as a subject in the world, which means recognizing the other as a subject of action. To act as a subject further implies that you are responsible for the consequences of your actions. Because a subject acts in a pluralistic context, s/he cannot know how his or her actions will be received (Biesta 2006: 48-49; Biesta 2013: 105-106). For this reason, subjectivity is not what happens independently to the other, but is a basic condition for the subject to be able to appear as a subject (Biesta 2006: 49; Biesta 2017: 11). "Plurality is the condition of human action," as Arendt writes (1998: 8).

If the purpose of education is to enable the student to appear as a subject, plurality becomes an important prerequisite in education. If the prerequisite of plurality is related to my classes in ethics, it can be interpreted as a need to allow many ethical perspectives to be presented, partly by highlighting different perspectives and partly by allowing all students (who wish) to present how they think about certain ethical questions. Also, as subjectivity emerges in plurality, I should convey to the students that they are responsible for the ethics

\footnotetext{
${ }^{8}$ It should be added that qualification, socialization, and subjectification are processes that always are happening while teaching, according to Biesta's reasoning. However, by highlighting these three purposes of education, he is able to argue that a language of learning does not enable the teacher to strike a good balance between all these three purposes. Most often only the purpose of qualification is valued through a language of learning, while the purpose of socialization and (especially) subjectification are marginalized or even ignored.
} 
they convey during the class and that their ethics can be challenged. Asserting yourself as an ethical actor is accordingly not only about presentation, but also about confrontation. For this reason, I should allow other students to express dissenting opinions, and challenge different students' basic assumptions by questioning their perspectives, as well as by presenting alternative perspectives.

While Arendt's works are important for understanding how subjectivity appears in plurality, Biesta argues that her thinking should be supplemented with Levinas. Based on Levinas' works, Biesta develops an understanding of how students can depart from what he describes as an "egocentric" relationship towards the world-something that Biesta believes Arendt's thinking risks reinforcing (Biesta 2017: 11, 13). For Levinas, the crucial question is not how I want to appear as a subject or how I want the world to respond to me. Levinas rather understands subjectivity as something that happens in the encounter with the other. Consequently, unlike Arendt, it is not because I act that my subjectivity is expressed. Rather, it is expressed because the one (or the thing) that is other calls me as a unique subject: "The [...] question precisely does not ask about everything I have to possess that would distinguish me from others, but looks for situations, for existential events, where my uniqueness is 'at stake' and where I am therefore at stake" (Biesta 2017: 12). For Levinas, it is when the other calls me to take responsibility when encountering the othera responsibility that one can choose to respond to or avoid, but always a responsibility that is directed at yourself and only yourself - that I as a subject can appear. Therefore, as Levinas explains, responsibility is "the essential, primary and fundamental structure of subjectivity” (Levinas and Nemo 1985: 95).

The crucial educational issue based on Arendt's works becomes how to enable a pluralistic context for subjectivity in teaching, as well as how to get students to recognize this plurality. Teaching based on Levinas' thinking, on the other hand, will entail helping the student to give up an egocentric perspective by creating opportunities where the student can appear as a unique subject. Biesta believes that the teacher can enable such opportunities by interrupting the student. Thus, the teacher has an educational purpose in forcing the student to appear as a subject by actively confronting or enabling someone else to confront the student ${ }^{9}$ with the one or the thing that is other-someone or something that is different and thus requires the student to make a choice. By interrupting the student, s/he must, therefore, reflect on their life orientation and evaluate whether it is worth continuing to walk along the path that they are on (Biesta 2017: 17).

According to Biesta, the interruption constitutes the most important educational purpose of a teacher who is willing to advance a process of subjectification while teaching a class. The consequence of such a "pedagogy of interruption," as Biesta calls it (Biesta 2006: 147-151), is that teaching often becomes a conflict-filled and emotional affair. Interestingly enough, he argues that teaching can be likened to a form of violence, in that the student's sovereign individuality is challenged through the interruption. Biesta writes: "To highlight that education entails a violation of the sovereignty of the student is, of course, not to suggest that education should be violent. It is only meant as a reminder that as teachers we are always interfering in the lives of our students and that this interference can have a deep, transforming, and even disturbing impact on our students" (Biesta 2006: 29).

\footnotetext{
${ }^{9}$ It is important to mention that the teacher, according to Biesta's reasoning, is not necessarily the one who interrupts, but the one who enables interruption. Accordingly, the interruption can be achieved through e.g. student participation.
} 
However, if subjectivity is emphasized as an important educational purpose (and subjectivity is understood according to Biesta's reasoning), the teacher needs to be cognizant of the potential adverse consequences of the interruption-teaching always entails a risk, according to Biesta's reasoning (Biesta 2013). As a teacher, you can never be sure how one's teaching (as interruption) will be received. Hopefully, the student recognizes the interruption as an opportunity for personal development. On the other hand, it is also possible that the teacher's attempts to interrupt the student leads to frustration and anger, and that the relationship between the teacher and the student consequently becomes strained (Biesta 2013: 55-56; Biesta 2017: 20). However, since the subject appears from an initial call from the one or the thing that is other, it is also by presenting the radically new that the teacher can appear as a teacher for the student. The teacher accordingly does not appear as a teacher by enabling learning, as the teacher is not necessarily needed for that purpose. Instead, the teacher becomes a teacher by intervening in the life of the student and offering him or her a choice. In the interruption, the student can accordingly appear as a subject that is confronted by a choice and who in choosing is required to take responsibility for his or her subjectivity.

\section{But What About Me?}

Biesta's philosophy of education primarily gives me two perspectives that are relevant for understanding my role as a teacher in ethics. The first is his focus on subjectification. This emphasis is important in that it creates a theoretical argument for making the teaching of ethics into something beyond certain learning-specific goals. Equally important is how teaching can help students grow as subjects, which is more difficult to capture in a syllabus. Ethics as a teaching subject is perhaps particularly suitable for such subjectification processes that Biesta accentuates since teaching often (and in my case, always) starts from the students' active participation through discussions. Furthermore, when taking a class in ethics, students are constantly forced to make ethical judgments, which, as Biesta points out, is part of acting as a subject. Based on Biesta's understanding of subjectification, the more or less inevitable process of subjectification should accordingly not only be understood as a natural consequence of teaching ethics. It should also be seen as a necessary part of teaching ethics.

Second, Biesta points to the need to highlight subject matters and perspectives that may be uncomfortable for the student. Subjectification can in many ways be a painful process, in that the student is forced to face the ego when confronted by the one or the thing that is other, thus potentially forcing the student to re-evaluate his or her ethical preconceptions as well as his or her understanding of the world and place in it. As mentioned, in this process the teacher has an important purpose in enabling the interruption, sometimes by acting as an agitator; someone who both challenges and provokes; someone who interrupts the student so that s/he can appear as a subject who is forced to make a choice. It is not possible for the teacher to know how students will receive this "gift" in advance. ${ }^{10}$ Education is thus a risk, but it is specifically in the perilous that Biesta believes that education (as enabling subjectification) can take place.

\footnotetext{
${ }^{10}$ Based on the works of Jacques Derrida, Biesta argues that teachers offer education as a "gift" to students (Biesta 2013: 53-54).
} 
While Biesta's works advance my understanding of the purpose of the teacher, he is not able to provide a satisfactory description of the teacher as an ethical actor. The question of whether I, as a teacher, can convey my ethical points of view is not the subject of Biesta's research. However, such a perspective is important for two reasons. First, if the teacher's purpose is to confront the student with the one or the thing that is other, it will, after all, be the teacher who chooses who or what is worth highlighting as an other. It is specifically in this choice that the teacher inevitably expresses an ethical judgment. With Karl Popper, we can therefore state: "[A] point of view is inevitable; and the naïve attempt to avoid it can only lead to self-deception, and to the uncritical application of an unconscious point of view" (Popper 2008: 289).

Second, students might interpret the act of interrupting as an indication of certain ethical sympathies, or at least as an attempt to legitimize a perspective that the students perceive as problematic, perhaps even offensive. This can happen even if the teacher carefully emphasizes that s/he is not expressing a personal ethical position. In such situations, as a teacher, I cannot always be comfortable with a perpetuation of an ensuing conflict. There is a limit to what I am prepared to sacrifice in terms of my reputation and relationship with the students. For this reason, I feel the need in these occasions to respond to students' potential animosity with a personal-ethical clarification. Both the fact that subjectification requires an ethical judgment by the teacher and that I am often forced to express my ethical positions, thus shows that I cannot pacify my agency as an ethical actor while teaching.

In order to resolve the question of the ethical agency of the teacher, Biesta's works must be supplemented. Specifically, I believe that the question on purpose in his philosophy of education needs to be refocused in a way that takes into account the empirical reality in which I and many other teachers are forced to reside. For this reason, Bruno Latour's political philosophy is briefly highlighted, especially his description of the diplomat's role in situations of conflict.

\section{The Democratic Society}

At the root of Latour's political philosophy is what could be described as a democratic vision for public life, which emphasizes that all actors who exist in a society should be allowed to present their concerns or have them presented. In order to create a theoretical foundation for the realization of this vision, he develops a critique of all actors who try to marginalize the public legitimacy of other actors. This critique is perhaps most clearly observed in his critique of those he describes as "the moderns," especially in the book We Have Never Been Modern (1991). ${ }^{11}$

Simply put, the crucial characteristic of the moderns is that they insist that they are modern-that is, that they have made a break with a period before modernity: "The adjective 'modern' designates a new regime, an acceleration, a rupture, a revolution in time" (Latour 1993: 10). The moderns accordingly assume that there was a period before modernity that the moderns believe that they have been able to escape. The identification as "modern" will therefore, as Latour writes, "[designate] a break in the regular passage of time, and

\footnotetext{
11 It is worth pointing out that the moderns function as an ideal type in Latour's writings (Latour 2013: 8). The purpose of describing the moderns is thus not to describe a people whose reality can be described with empirical data. Instead, it is to point to some contemporary trends that generally speaking characterize modernity.
} 
it designates a combat in which there are victors and vanquished" (Latour 1993: 10). The moderns thus believe that they are the heirs of those who brought the hope of enlightenment into a dark and archaic world. In order to create the conditions for an enlightened reality for all, they therefore challenge those actors whose basic rational and practical outlook is incompatible with modern rationality. Instead, the moderns advocate a rational and practical outlook that is based on immanent qualifications. Furthermore, the moderns reason that the path towards enlightenment that they are the heirs to is the only rational outlook that can potentially gain universal legitimacy. For this reason, Latour describes the moderns as universalists (Latour 1993: 112).

While there is much in modern rationality that Latour thinks is worth retaining (Latour 1993: 132-133, 135; Latour 2013), he is critical of modern universalism, in that it creates a hierarchical order between the moderns and those that are perceived to be premodern. Such an attitude, where one imagines that one represents a more legitimate and superior rationality, is problematic according to Latour's reasoning, in that it creates rational conditions that are capable of depriving the public legitimacy of certain social actors (Latour 1993: 10-11). This critique is furthermore not only directed at the moderns. It permeates Latour's work. Therefore, this critique also appears when he discusses, e.g. social scientists' marginalization of the social actors that they study (Latour 2005) and humanity's depletion of the planet (Latour 2017). ${ }^{12}$

As an alternative to such marginalization, he advocates for a public that strives for and prioritizes a more inclusive public. Somewhat simplified, his works advances the idea that such a public is achieved by creating practices and structures that enable everyone's concerns to be presented publicly. ${ }^{13}$ Only when such an egalitarian order has emerged can a society, according to Latour's thinking, claim that it is open and democratic.

As Latour further argues, this will also entail that the actors whose concerns are presented in the public sphere are brought together into a common collective-they must exist in the same public arena, not in different contexts without any connections to one another. In order for them to do so, these actors must endeavor to form associations with each other in order to form a common network of actors. ${ }^{14}$ The presentation of concerns therefore enables the formation of a collective body politic of free actors. But since the actors who need to be allowed to be presented always fluctuate, and as their concerns change, the body politic has no lasting stability. Instead, it will be, as Latour writes, "a temporarily defined totality" (Latour 2003: 147-148). This means that an open and democratic society is something that arises temporarily when free actors are allowed to present their concerns in public life. And to the extent that freedom (to present ones concerns) is stymied, the idea of an open and democratic society will also be threatened (Latour 2003).

\footnotetext{
12 One of the more debated views that Latour advances is that an actor does not necessarily need to be understood as human, but also non-human actors are alleged to have agency in the public sphere. See (Latour 2005: 71-78) In the same way that he criticizes certain actors' attempts to marginalize the public legitimacy of some people, he is thus also critical of the marginalization of the planet's concerns.

${ }^{13}$ Latour believes that a society can only be considered as "political" if there is an effort to present all the concerns within a society publicly. He consequently defines politics as "re-presentation," with which he wants to emphasize that the presentation of actors' affairs is a process that constantly needs to be repeated (re-) in public life (Latour 2003).

14 I have previously argued that Latour's works on Actor-Network-Theory-the scientific-theoretical perspective that has made him a well-known name within mainly the social sciences-should be understood as an expression of his political philosophical work (Portin 2016).
} 
An important point Latour makes is that this emphasis on presentation should not be perceived in such a way that all matters of concern are legitimate after they have been presented. On the contrary, presentation is only the first step towards a process of evaluating and judging between the various concerns: "If there is a mistake that, for our own salvation, we must not commit, it is that of confusing respect for the various alterations [...] with the resources of critical thought" (Latour 2013: 157). Since everything does not contribute to the common good, it is therefore obvious that everything should not be valued equally: "Yes, there are things to discuss [...] there are beings that do not deserve to exist [...] we have to judge and decide" (Latour 2013: 142-143). However, Latour's point is that no such evaluation can be made unless an initial presentation has taken place-something that he argues all too often does not happen and which he thus criticizes. It is consequently by highlighting the dividing lines that one can begin to find new ways towards a common future beyond these dividing lines. For this reason, one could say that the objective of politics is the creation of a future association between different actors, which is based on the recognition that such associations are impossible as long as marginalization and exclusion are allowed. Thus, the presentation of all matters of concern allows conflicts between different actors to surface, consequently allowing them to be confronted for the purpose of creating a common future together. Therefore, only when conflicts are allowed to be confronted, is it possible to "perhaps, [...] speak of democracy again," as Latour writes (Latour 2013: 142).

In this endeavor to make all concerns public, a resemblance to Biesta's thinking emerges. It can specifically be argued that the space for education corresponds to the public arena for presentation that Latour imagines. Both are arenas for plurality. Also, they both create the conditions for evaluating what is worthwhile pursuing and/or supporting. For Latour, it is about evaluating what concerns contribute to the general good. For Biesta, it is about creating the conditions for the student to make a decision-thus, to evaluate what is worth desiring —in order to make him or her appear as a subject.

However, what Latour to a greater extent than Biesta touches upon, is how to deal with conflicts between different actors, in my case students. As both argue, a consequence of plurality is conflict. This can be the beginning of a beneficial development for society and/ or the subject. But conflicts can also give rise to antagonism (and even violence). As I have already noted, this is a particular challenge when teaching ethics, as the questions that often are addressed tend to give an emotional response. How I, as a teacher, should deal with such antagonism thus becomes a principal concern. In addressing this concern, Latour's interpretation of the role of the diplomat provides some valuable theoretical perspectives.

\section{An Endeavour Towards Peace}

In the book War of the Worlds (2002) Latour likens the desire to present one's concerns with the willingness to go to war. He does not want to encourage violence but believes that conflict is inevitable in the democratic public that he imagines. It can furthermore be argued that a distinct feature of modern liberal democracies has been to avoid conflict by developing a consensus-based model of politics that sees conflict as a political deficit (Mouffe 2005: 1-2, 31-32). However, instead of avoiding conflicts, Latour wants them to be confronted (Portin 2016: 188). He accordingly wants actors to "go to war" so that the conflicts that an inclusive public causes can be confronted: "In contrast to the history that sought to modernize, the West has to admit to the existence of war in order to make peace: 
to accept that it has had enemies, to take seriously the diversity of worlds [and] to refuse to accept mere tolerance" (Latour 2002: 29). However, the challenge of violence remains, and that is one of the reasons why Latour highlights the need for diplomacy.

The purpose of the diplomat is not to conquer the public space by offering already predetermined solutions and answers to an ongoing conflict. Instead, the diplomat invites the conflicting parties to negotiations with the hope that they will be able to pursue a common future together after the negotiations have ended. Latour writes:

Diplomats know that there exists no superior referee, no arbiter able to declare that the other party is simply irrational and should be disciplined. If a solution is to be found, it is there, among them, with them here and now and nowhere else. Whereas [the moderns] would not know how to assemble peace talks, as they will not give seats to those they call "archaic" and "irrational," diplomats might know how to organize a parley among declared enemies (Latour 2002: 37. Cf. Latour 2013: 35-36).

For the purposes of this essay, it is important to emphasize that diplomats are not impartial public actors - there is no neutrality to be had in peace negotiations, according to Latour's reasoning. Diplomats have loyalties to a specific collective (or network, as Latour would say) and will therefore to some extent represent this collective. For example, if USA and Russia were in a conflict with each other, USA would send its diplomat and Russia its diplomat, both of which are not impartial. However, Latour also argues that the diplomats know that the collectives they are loyal to are susceptible to change. Accordingly, as the inclusive public that Latour imagines does not adapt to universalist claims, the diplomat knows that the perspectives of one's own collective have no greater validity than the perspectives of others: "[The diplomat] knows in advance that they are 'all equally false"' (Latour 2004: 212).

From such a stance, Latour reasons, the diplomat is more capable than others to present the various concerns of the conflict, without presenting the concerns of his or her collective as more important and worthy of privilege. Instead, they are presented as equally important. However, not all concerns are equally worthwhile presenting. Another important purpose of the diplomat, according to Latour, is to present the various concerns so that the different actors can confront those concerns that initiated the conflict. All potential matters of concern do not need to be confronted. Accordingly, without the diplomat highlighting the concerns that obstruct a future peace, the actors have, according to Latour, no possibility to "differentiate between what is essential and what is superfluous." Without diplomacy, therefore, the actors will "go to war over anything, because [they see] everything as equally necessary" (Latour 2004: 214).

In order for the diplomat to be able to decide which matters of concern are worth highlighting and must be confronted in order to achieve a future peace, s/he needs to enact judgment. Instead of getting caught up in what does not require any confrontation, the diplomat accordingly judges and highlights those concerns that constitute the actors' utmost concerns. These concerns mark fundamental differences between the different collectives, and it is accordingly only by confronting these differences that a common future can be realized (Latour 2004: 212-213, 217). ${ }^{15}$ It is again important to emphasize that these utmost concerns are not highlighted in order to trivialize them. Instead, the purpose is to

\footnotetext{
15 As the conflict researcher Michelle LeBaron notes, one can be in conflict over many things, even those that are trivial. However, she also points out that not all conflicts are relevant in peace processes: "Conflict, put simply, is a difference that matters" (LeBaron 2003: 11).
} 
confront those concerns that, according to the diplomat's judgement, obstruct a future and common peace between different actors (Latour 2004: 216-217).

The diplomat's goal is specifically this common peace. At the same time as s/he presents the various concerns that are in conflict, s/he also highlights a future peace that the confrontation enables. The diplomat presents all relevant concerns with the hope that former enemies, as Latour writes, "may become allies after the peace negotiations have ended" (Latour 2002: 37). The diplomat's purpose is not simple, and the common future s/ he imagines does not arrive without (often great) friction. Confronting a conflict is consequently always a risky project and has no guaranteed path to success (Latour 2004: 215). However, in light of Latour's democratic vision for society, diplomacy will be necessary, as it enables that the relevant concerns become presented and that a peace process can commence between enemies.

\section{The Diplomatic Teacher}

Although Biesta and Latour discuss different issues, there are several similarities in their thinking. First, they both describe conflicts as something constructive. For Biesta, this view on conflict appears when discussing the teacher's purpose of interrupting students. The interruption, where the student is forced out from his or her egocentric perspective in order to confront the one or that which is other, creates a conflict. This conflict enables the student to appear as a subject by choosing what is worth desiring. Latour, on the other hand, shows how the existence of the conflict in public life is an opening for a new future between different actors. Second, they both want everyone to appear as actors in public life. For Biesta, the crucial question is how a student can appear as a subject. For Latour, the crucial concern is to create the necessary (theoretical) conditions for different actors to be able to appear as actors, especially by criticizing the actors who try to prevent others from expressing their agency.

Although Latour does not directly discuss the role of the teacher, I argue that his description of the role of the diplomat contributes to Biesta's work, specifically by developing Biesta's initial reasoning on the purpose of education. In the question of educational purpose, Biesta gives priority to subjectification. In contrast, from Latour's description of diplomacy, peace becomes a priority in education. The priority of peace requires subjectification-it is because different subjects appear and act while they are being taught that those conflicts arise that require the endeavor towards peace. However, by highlighting peace as a priority, a clearer recognition of the teacher's ethical agency is highlighted, something that Biestas reasoning lacks.

The fact that the diplomat has agency is not a condition that must be overcome in order for peace to occur between different parties. Instead, it is a reality that must be recognized in order for the diplomat to be able to function as a diplomat. To claim that a diplomat is neutral in peace negotiations is to misinterpret the diplomat's position completely. Instead, the diplomat is an actor with his or her agency and loyalties. There is, therefore, no reason to try and conceal this agency due to a mistaken understanding of the diplomat's capacity for neutrality. What makes the diplomat unique, however, is specifically that s/he makes peace the ultimate purpose of his or her agency. Accordingly, although $\mathrm{s} / \mathrm{he}$ has his or her desires, s/he prioritizes the creation of opportunities for peace between different actors. 
If the reasoning above is related to the role of the teacher, it will be the teacher's responsibility to enable peace between different actors in conflict. However, this responsibility does not require that the teacher function as a neutral actor. For this reason, the teacher's agency should be clarified, both for the teacher himself or herself, and the students. By turning the educational purpose into peace-a peace that becomes necessary as a result of subjectification-critique of the teacher's expression of ethical agency can be met. According to the reasoning advanced in this essay, the teacher cannot help acting as an ethical actor. And if neutrality is expected, one will thereby marginalize the teacher as an ethical actor. Furthermore, one misinterprets the actual context where teachers often have to work.

On the other hand, it is important to emphasize that Latour's description of diplomacy also highlights that the teacher must show judgment in terms of appearing as an ethical actor. Expressing ethical agency is not in itself in conflict with the role of the (diplomatic) teacher. However, it is not always necessary for the teacher to express an ethical outlook. Everything that the teacher can present is not always worth presenting, as everything does not contribute to the peace process. The teacher must, therefore, sift between what concerns are important to highlight and thus worthy of being confronted, and which concerns are trivial and thus merely obstruct or derail the endeavor towards peace. Thus, the teacher needs to have judgement in order to be able to highlight that which contributes to the peace process, while avoiding what is unnecessary.

In order to obtain this judgment, wisdom is unquestionably needed. ${ }^{16}$ Equally important, however, is the realization that one's ethical perspectives do not necessarily have universal legitimacy. The essence of ethics is change and conflict, and to claim that one's perspectives have greater legitimacy than any other, makes subjectivity and plurality impossible. Therefore, if the teacher can relate to his ethical perspectives from a more "relativistic" stance (cf. Latour 1993: 111-114; Latour 2005: 23-24), the need for the teacher to make explicit his or her ethical agency is (hopefully) seldom needed (cf. Biesta 2017: 18). Instead, the teacher can express wisdom through the realization that something new can occur at any time when encountering the one or that which is other. This does not only apply to the students. As an ethical actor, the teacher can also be forced to radically reevaluate the ethical perspectives that s/he holds. This insight should accordingly further assist the teacher to humbly asses the value of his or her ethical perspectives, thus putting the main focus on the endeavor towards peace rather than the advancement of his or her ethical perspectives.

\section{Concluding Remarks}

The purpose of this essay was to discuss two main questions: (1) what educational purpose does it serve to challenge students as ethical subjects while teaching a class? (2) How should teachers relate to their ethical agency when challenging the students as ethical subjects?

I addressed the first question through a reading of Gert Biesta's philosophy of education. He emphasizes subjectification as an important educational purpose. This subjectification is enabled by creating opportunities for the student to appear as a subject. The

\footnotetext{
${ }^{16}$ Here Latour's thinking can be linked to Biesta's description of the education of teacher students. Biesta points out that teachers of teacher students need to obtain practical wisdom-what ancient philosophy describes as phronesis - in order to be able to function as good teachers. This is further achieved by being educated in virtues that enable the teacher to make good judgments (Biesta 2013: 119-137).
} 
process of subjectification is further realized by challenging the student's "egocentric" orientation in life, by presenting the one or that which is other to the student. By interrupting the student in this way, s/he is forced to appear as a subject, in that s/he must choose as a subject in relation to that which is different. Related to my classes in ethics, it therefore becomes natural that I challenge the students by "provoking" the subject to appear, while also offering students the opportunity to challenge other students and myself. Thus, by constantly interrupting students in their ethical reasoning by presenting alternative, sometimes controversial, perspectives, they must (re)evaluate their ethical attitude. In this manner, teaching ethics can contribute to the student's process of subjectification.

The second question was mainly addressed by highlighting Bruno Latour's political philosophy. If a teacher takes on such a provocative role that Biesta's thinking suggests, then the question of the teacher's ethical agency will come into focus. By emphasizing the diplomatic role of the teacher, it is possible to challenge the notion that the teacher is a neutral, ethical actor. The diplomat's goal is to create peace between different actors in conflict, and as a diplomat, the teacher therefore has a responsibility to create the conditions for a future relationship between actors currently in conflict. However, as a diplomat, the ethical agency of the teacher is not put into question. But the diplomat is also someone who has the judgement to decide what parts of his or her ethics is relevant for advancing the peace process (a process where the diplomat him- or herself can be said to be an actor among many others in conflict), and when it is worth highlighting his or her ethical perspectives. Based on Latour's reasoning, it is thus possible to express an ethical attitude while teaching ethics. However, as a teacher, my ultimate responsibility is the endeavor towards peace. Accordingly, this entails that I have the capacity to judge what should be said and what should be left unsaid.

Hence, the diplomatic teacher is a teacher in the truest sense, as s/he is an actor who has the responsibility and judgement to determine how the student best achieves the educational purposes while teaching a class.

For me, this understanding of the role of the teacher provides a theoretical basis from which my teaching can be based in the future. Additionally, as my role has been clarified, I can also more clearly convey it to the students by presenting my role at the beginning of each class in ethics. While I do not think this will prevent conflicts between myself and the students - which is not necessarily desirable-I can thus hopefully limit the instances where the conflicts lead to or come close to antagonism.

Whether this description of the teacher's role is applicable in contexts other than my own, each teacher may decide for him- or herself. My hope, on the other hand, is that this essay can serve as a text that teachers and teacher students can so to say "think with." The purpose was thus not to give a definitive answer to the two main questions that this essay has discussed. Instead, it is to offer some theoretical perspectives that can serve as a basis for continued reflection on the teacher's role in ethics and the role of other teachers that face the same challenges as myself. I accordingly ask that current and future teachers use their judgement when assessing the applicability of the perspectives raised in this essay.

Acknowledgements Open access funding provided by University of Gothenburg. This essay was made possible by a Grant from The Society of Swedish Literature in Finland.

Open Access This article is licensed under a Creative Commons Attribution 4.0 International License, which permits use, sharing, adaptation, distribution and reproduction in any medium or format, as long as you give appropriate credit to the original author(s) and the source, provide a link to the Creative Commons 
licence, and indicate if changes were made. The images or other third party material in this article are included in the article's Creative Commons licence, unless indicated otherwise in a credit line to the material. If material is not included in the article's Creative Commons licence and your intended use is not permitted by statutory regulation or exceeds the permitted use, you will need to obtain permission directly from the copyright holder. To view a copy of this licence, visit http://creativecommons.org/licenses/by/4.0/.

\section{References}

Arendt, Hannah. 1998. The human condition, 2nd ed. Chicago: University of Chicago Press.

Biesta, Gert. 2006. Beyond learning: Democratic education for a human future. Interventions. Boulder: Paradigm Publishers.

Biesta, Gert. 2013. The beautiful risk of education. Boulder: Paradigm Publishers.

Biesta, Gert. 2016. Good education in an age of measurement: Ethics, politics, democracy. London: Routledge.

Biesta, Gert. 2017. The rediscovery of teaching. New York: Routledge.

Calhoun, Craig J., Mark Juergensmeyer, and Jonathan VanAntwerpen (eds.). 2011. Rethinking secularism. Oxford: Oxford University Press.

Campbell, Elizabeth. 2003. The ethical teacher. Maidenhead: Open University Press.

Campbell, Elizabeth. 2008. The ethics of teaching as a moral profession. Curriculum Inquiry 38: 357-385.

Carr, David. 1993. Questions of competence. British Journal of Educational Studies 41: 253-271.

Fenstermacher, Gary D. 2001. On the concept of manner and its visibility in teaching practice. Journal of Curriculum Studies 33: 639-653.

Habermas, Jürgen. 2008. Notes on post-secular society. New Perspectives Quarterly 25: 17-29.

Hansen, David T. 2001. Exploring the moral heart of teaching: Toward a teacher's creed. New York: Teachers College Press.

Harman, Graham. 2014. Bruno Latour: Reassembling the political. London: Pluto Press.

Kurtén, Tage. 1995. Tillit, verklighet och värde: Begreppsliga reflexioner kring livsåskådningar hos fyrtioen finska författare. Nora: Nya Doxa.

Latour, Bruno. 1993. We have never been modern. Cambridge: Harvard University Press.

Latour, Bruno. 2002. War of the worlds: What about peace?. Chicago: Prickly Paradigm Press.

Latour, Bruno. 2003. What if we talked politics a little? Contemporary Political Theory 2: 143-164.

Latour, Bruno. 2004. Politics of nature: How to bring the sciences into democracy. Cambridge: Harvard University Press.

Latour, Bruno. 2005. Reassembling the social: An introduction to actor-network-theory. Oxford: Oxford University Press.

Latour, Bruno. 2013. An inquiry into modes of existence: An anthropology of the moderns. London: Harvard University Press.

Latour, Bruno. 2017. Facing Gaia: Eight lectures on the new climatic regime (trans: Porter, Catherine). Cambridge: Polity.

LeBaron, Michelle. 2003. Bridging cultural conflicts: A new approach for a changing world. San Francisco: Jossey-Bass

Levinas, Emmanuel, and Philippe Nemo. 1985. Ethics and infinity. Pittsburgh: Duquesne University Press.

Moberg, Marcus, Kennet Granholm, and Peter Nynäs. 2012. Trajectories of post-secular complexity: An introduction. In Post-secular society, ed. Peter Nynäs, Mika Lassander, and Terhi Utriainen, 1-25. New Brunswick: Transaction Publishers.

Mouffe, Chantal. 2005. On the political. London: Routledge.

Nancy, Jean-Luc. 1991. Introduction. In Who comes after the subject?, ed. Eduardo Cadava, Peter Connor, and Jean-Luc Nancy, 1-8. New York: Routledge.

Popper, Karl. 2008. The open society and its enemies, vol. 2: Hegel and Marx. London: Routledge.

Portin, Fredrik. 2016. Hopp om en okänd framtid: Förutsättningar för en inklusiv offentlighet utifrån Bruno Latours och Alasdair MacIntyres tänkande. Turku: Åbo Akademi University Press.

Sockett, Hugh. 1996. Can virtue be taught? The Educational Forum 60: 124-129.

Winter, Philip, and Gert Biesta. 2013. Coming into the world, uniqueness, and the beautiful risk of education. In The beautiful risk of education, 141-148. Boulder: Paradigm Publishers.

Publisher's Note Springer Nature remains neutral with regard to jurisdictional claims in published maps and institutional affiliations. 